\title{
The effect of a model melanoidin mixture on faecal bacterial populations in vitro
}

\author{
Jennifer M. Ames*, Anthony Wynne, Andrea Hofmann, Saskia Plos and Glenn R. Gibson \\ Department of Food Science and Technology, The University of Reading, Whiteknights, PO Box 226, Reading RG6 6AP, UK
}

(Received 6 January 1999 - Revised 17 May 1999 - Accepted 11 June 1999)

\begin{abstract}
The Maillard reaction produces coloured, macromolecular materials (melanoidins) in a variety of foods, on heating. Significant quantities may enter the human gut on a daily basis, but there is little information on their metabolism in the human colon. As the large bowel contains a diverse population of bacteria involved in normal bowel function, it is possible that melanoidins are metabolized therein. Depending on the bacteria involved, there may be disease or health implications. The aim of the present study was to use in vitro models to determine the digestibility of melanoidins and the effect of melanoidins on colonic bacteria in the gastrointestinal tract. Melanoidins were prepared and the effects of simulated upper-gut secretions on their stability determined in a model system. The effects of faecal bacteria were also determined, in batch culture, with a combination of phenotypic and genotypic (probes) criteria being used to identify the microbial diversity involved. Simulation of peptic and pancreatic digestion showed that the melanoidins did not produce detectable amounts of low-molecular-mass degradation products. However, melanoidins affected the growth of gut bacteria during mixed culture growth. The effect was to cause a non-specific increase in the anaerobic bacteria enumerated. This in vitro study indicates that melanoidins can affect the growth of human large-bowel bacteria and serves to demonstrate possible effects that may occur in vivo. Given the large and varied number of food items that contain Maillard reaction products, this may have relevance for lower-gut health.
\end{abstract}

\section{Maillard reaction: Melanoidins: Gut fermentation: Gene probes}

The Maillard reaction is a complex network of reactions that occurs in both food and the human body (O'Brien et al. 1998). It occurs when reducing sugars, like glucose and lactose, react with components possessing a free amino group, such as amino acids and peptides (Ledl \& Schleicher, 1990; Ames, 1992). The final products of the reaction are coloured, macromolecular materials known as melanoidins, which are ubiquitous components in the typical Western diet (Ames, 1998). Structures of melanoidins and related materials are poorly defined (Ames \& Nursten, 1989; Rizzi, 1997). No single melanoidin has been isolated and characterized.

The degradation of melanoidins under physiological conditions and the effects of micro-organisms on Maillard reaction products have been reviewed (O'Brien \& Morrissey, 1989). Studies using rats indicated that only a small proportion of melanoidins prepared from glucose and glycine (or lysine) were absorbed through the gut wall, most being excreted in faeces (Finot \& Magnenat, 1981; Homma \& Fujimaki, 1981; Nair et al. 1981; Finot, 1990; Lee et al. 1992). However, $90 \mathrm{~d}$ toxicity studies of Class I and Class IV caramels using rats resulted in discolouration of the mesenteric lymph nodes that was attributed to the intestinal absorption of high-molecular-mass caramel components (Noltes \& Chappel, 1985).

Investigations involving melanoidins and micro-organisms have hitherto focused on (a) the potential of melanoidins to affect the growth of bacteria, including the possible extension of food shelf-life (e.g. Viswanathan \& Sarma, 1957; De Lara \& Gilliland, 1985), (b) the ability of micro-organisms to degrade or decolorize melanoidins (Murata et al. 1992; Terasawa et al. 1996) and, (c) the effect of melanoidins on gut microflora composition (Jemmali, 1969; Horikoshi et al. 1981). There is very little information on microbial interactions between human colonic bacteria and Maillard reaction products.

The colon is the most metabolically active site in the human body. This is because of the resident microbiota, which comprises about $10^{14}$ prokaryote cells in total (Salminen et al. 1998). The nature of the gut fermentation may impact heavily on host health and welfare (Freter, 1983) and the gut flora is thought to play a central role in homeostasis, digestion and the prevention of diseases, such as acute gastroenteritis and bowel cancer (Roberfroid et al. 1995; 
Gibson et al. 1996). Probiotics and prebiotics have been developed to help maintain, or even improve, the gut microbiota composition, i.e. sustain benign or beneficial species residing in the gut (Fuller, 1992, 1997; Gibson \& Roberfroid, 1995).

Bacteriological metabolism can be monitored by determining the formation of typical fermentative end-products like short-chain fatty acids and gases. However, this approach is limited in that it is important to identify the bacteria involved in metabolism, as it is recognized that the gut flora contains potentially pathogenic as well as harmless groups (Simon \& Gorbach, 1984; Gilliland, 1990; Fuller \& Gibson, 1997).

Microbiological changes in response to the fermentation of growth substrates are usually carried out by plating onto selective agars. However, the approach does have serious limitations, e.g. the media are never wholly selective and the technique is subject to operator subjectivity.

Molecular procedures have recently been applied to gastrointestinal microbiology (Kok et al. 1996; McCartney et al. 1996; Wilson \& Blitchington, 1996; Salminen et al. 1998; Collins \& Gibson, 1999). One such approach, that offers increased reliability over plating procedures, is the application of 16S rRNA-targetted probes (Langendijk et al. 1995). Here, a faecal specimen may be treated with a battery of oligonucleotide probes designed to hybridize with major components of the gut flora. To facilitate quantification, the probes are labelled with a fluorescent marker and applied in an in situ hybridization technique (fluorescent in situ hybridization, FISH).

In the present paper, we report the metabolism of melanoidins by human gut bacteria. Melanoidins were prepared from an aqueous glucose-lysine model system. We used in vitro systems to determine the degree of melanoidin degradation in the upper gastrointestinal tract and to assess the fermentation of melanoidins by human gut bacteria by a combination of phenotypic and FISH techniques.

\section{Methods}

\section{Materials}

Chemical reagents for the fermentation studies were obtained from Sigma (Gillingham, Dorset, UK). The bacterial culture reagents were from Oxoid (Basingstoke, Hants., UK), whilst oligonucleotide probes were synthesized and labelled by Eurogentec UK Ltd (Abingdon, Oxon., UK). D-(+)-Glucose (ACS grade) and L-lysine monohydrochloride $(99+\%$ grade, which was subsequently recrystallized from $100 \mathrm{ml} / 1$ aqueous ethanol), for preparing the melanoidins, were obtained from Aldrich (Gillingham, Dorset, UK). Pepsin (porcine, EC 3.4.23.1, catalogue no. P7000), pancreatin, containing many enzymes including amylase, trypsin, lipase, ribonuclease and protease, no $E C$ number stated (porcine, catalogue no. P1750), and bile (porcine, catalogue no. B8631) were obtained from Sigma. Methanol for HPLC was obtained from Rathburn Chemicals Ltd (Walkerburn, Borders, UK) and water for HPLC was prepared in the laboratory using a Purite Labwater RO50 unit (Purite Ltd, High Wycombe, Bucks., UK).

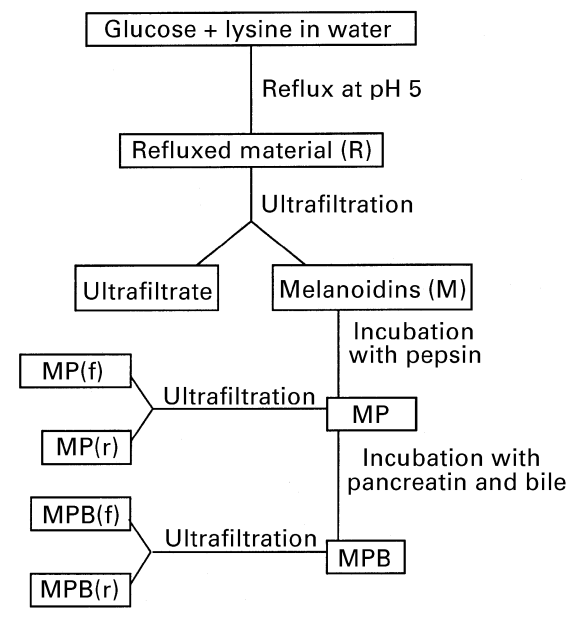

Fig. 1. Preparation of melanoidins and their in vitro digestion.

\section{Preparation of melanoidins}

Fig. 1 summarizes the preparation of melanoidins and their subsequent incubation and digestion. Preparation of the melanoidins was as described by Bailey et al. (1996) and Royle et al. (1998). Briefly, a solution of lysine (0.1 mol) and glucose $(0.1 \mathrm{~mol})$ in $100 \mathrm{ml}$ water was refluxed for $2 \mathrm{~h}$ with the $\mathrm{pH}$ maintained at 5 throughout heating by the intermittent addition of $3 \mathrm{M}-\mathrm{NaOH}$ solution and $\mathrm{pH}$ monitoring using an autoclavable electrode. The resulting material, $\mathrm{R}(15 \mathrm{ml})$, was subjected to ultrafiltration using an Amicon ultrafiltration cell model 8050 (Amicon, Beverly, MA, USA), equipped with a $3000 \mathrm{Da}$ nominal molecular mass cut-off membrane, to give a retentate volume of about $2 \mathrm{ml}$. The retentate was washed by diluting with water $(5 \mathrm{ml})$ and reduced to about $0.5 \mathrm{ml}$ using the $3000 \mathrm{Da}$ membrane. This washing procedure was repeated twice more, in order to remove low-molecular-mass material. The final retentate was diluted to $3 \mathrm{ml}$ with distilled water to give the melanoidin sample, $\mathrm{M}$. This sample was subjected to elemental analysis in duplicate.

\section{In vitro digestion}

The fate of melanoidins under conditions that attempted to simulate those in the stomach and small intestine was examined using in vitro model systems, based on the procedure described by Minihane et al. (1993). Sample M $(1 \mathrm{ml})$ was diluted with $30 \mathrm{ml}$ distilled water. After adding freshly prepared pepsin $(3 \cdot 2 \mathrm{~g} / 20 \mathrm{ml} 0 \cdot 1 \mathrm{M}-\mathrm{HCl})$, the $\mathrm{pH}$ was adjusted to 2.0 using $6 \mathrm{M}-\mathrm{HCl}$. The weight of the sample was adjusted to $50 \mathrm{~g}$ with distilled water and the mixture was incubated at $37^{\circ}$ in a shaking waterbath to give sample MP. Sample MP (20 g) was adjusted to $\mathrm{pH} 7$ using $0.5 \mathrm{M}-$ $\mathrm{NaHCO}_{3}$ and $15 \mathrm{ml}$ was subjected to ultrafiltration using the $3000 \mathrm{Da}$ membrane. The resulting filtrate and retentate were called MP(f) and MP(r) respectively.

Sample MP $(25 \mathrm{~g})$ was mixed with $5 \mathrm{ml}$ freshly prepared pancreatin-bile mixture $(0.4 \mathrm{~g}$ pancreatin and $2.5 \mathrm{~g}$ bile in $\left.100 \mathrm{ml} 0 \cdot 1 \mathrm{M}-\mathrm{NaHCO}_{3}\right)$. The $\mathrm{pH}$ of the mixture was adjusted to 7 over $30 \mathrm{~min}$ using $0 \cdot 5 \mathrm{M}-\mathrm{NaHCO}_{3}$, before incubating at $40^{\circ}$ for $2 \mathrm{~h}$ in a shaking waterbath to give sample MPB. 
Sample MPB (15 ml) was subjected to ultrafiltration using the $3000 \mathrm{Da}$ membrane and the filtrate, $\mathrm{MPB}(\mathrm{f})$, was collected.

Incubations were also performed without melanoidins and without enzymes. All incubations were performed in triplicate.

Melanoidins and samples derived from them were analysed by HPLC using a reverse-phase octadecasilica column and a water-methanol gradient with diode array detection and monitoring at $280 \mathrm{~nm}$ (Bailey et al. 1996).

\section{Bacteriological fermentation}

Anaerobic batch culture fermenters were operated at $37^{\circ}$. The basal growth medium contained (per litre): $1 \mathrm{~g}$ yeast extract, $1 \mathrm{~g}$ peptone water, $0.05 \mathrm{~g} \mathrm{NaCl}, 0.02 \mathrm{~g} \mathrm{~K}_{2} \mathrm{HPO}_{4}$, $0.02 \mathrm{~g} \mathrm{KH}_{2} \mathrm{PO}_{4}, 0.005 \mathrm{~g} \mathrm{MgSO}_{4} .7 \mathrm{H}_{2} \mathrm{O}, 0.005 \mathrm{~g} \mathrm{CaCl}_{2} .6 \mathrm{H}_{2} \mathrm{O}$, $1 \mathrm{~g} \mathrm{NaHCO}_{3}, 1 \mathrm{ml}$ Tween 80, 0.025 g haemin, $5 \mu \mathrm{l}$ phylloquinone, $0.25 \mathrm{~g}$ cysteine $\mathrm{HCl}$ and $0.25 \mathrm{~g}$ bile salts. Initially, three fermenters were set up containing melanoidins (M), digested melanoidins (MPB), each at a final concentration of $10 \mathrm{~g} / \mathrm{l}$, and no melanoidins (control) respectively. This experiment was monitored using plate counts only. The second fermentation experiment was carried out in triplicate with melanoidin (M) at $10 \mathrm{~g} / \mathrm{l}$ and the microflora were enumerated using both phenotypic and genotypic characterization methods. The operating volume of the fermenters was $50 \mathrm{ml}$ and contained a final concentration of $10 \mathrm{~g}$ faeces/l. Samples were donated by three healthy volunteers (one female, two males, aged 25-37 years) who had not been taking antibiotics for at least 3 months before the study and had no history of gastrointestinal disorder. Fermenters were inoculated immediately after the stools had been passed. Samples for bacterial analysis and ultrafiltration were removed after 0,6 and $24 \mathrm{~h}$. Ultrafiltrates were analysed by HPLC (Bailey et al. 1996). The experiments were carried out in triplicate.

\section{Cultural identification of gut bacteria}

Three $1 \mathrm{ml}$ samples were removed from each fermenter and were serially diluted (up to $10^{-12}$ ) in an anaerobic cabinet $\left(\mathrm{H}_{2}-\mathrm{CO}_{2}-\mathrm{N}_{2}, 10: 10: 80\right.$, by vol.), using $500 \mathrm{~g} / \mathrm{l}$ peptone water with $0.5 \mathrm{~g} / \mathrm{l}$ cysteine $\mathrm{HCl}(\mathrm{pH} 7)$, and plated out, in triplicate, onto agar plates designed to select for the predominant groups of gut anaerobes. These were bacteroides, bifidobacteria, lactobacilli, clostridia and total anaerobes (Table 1). After incubation, colonies were enumerated and identified. Details of the cultivation technique and phenotypic identification of isolates were as described by Wang \& Gibson (1993) and Gibson et al. (1995).

\section{Detection of gut bacteria by $16 S$ rRNA probes}

The probes used in the study were Bif164 (Langendijk et al. 1995), Bac303 (Manz et al. 1996), His150 (Franks et al. 1998) and Lab158 5'GGTATTAGCA(T/C)CTGTTTCCA, specific for bifidobacteria, bacteroides, clostridia (Clostridium perfringens/histolyticum subgroup) and lactobacillienterococci respectively. The probes were commercially synthesized and 5'-labelled with the fluorescent dye Cy3 (Eurogentec UK Ltd). The nucleic acid stain 4',6diamidino-2-phenylindole (DAPI) was used for total bacterial counts (Porter \& Feig, 1980). Samples were diluted $(1: 3$, $\mathrm{v} / \mathrm{v}$ ) and fixed overnight at $4^{\circ}$ with $40 \mathrm{ml} / \mathrm{l}$ paraformaldehyde. These cells were then washed with PBS $(0 \cdot 1 \mathrm{M}$, $\mathrm{pH} 7 \cdot 0$ ), resuspended in a mixture of PBS $-100 \%$ ethanol $(1: 1, \mathrm{v} / \mathrm{v})$ and stored at $-20^{\circ}$ (Langendijk et al. 1995). The cell suspension $(32 \mu \mathrm{l})$ was then added to $200 \mu \mathrm{l}$ prewarmed hybridization buffer (40 mM-Tris- $\mathrm{HCl}, 1.8 \mathrm{M}-\mathrm{NaCl}, 2 \mathrm{~g} / \mathrm{l}$ SDS, $\mathrm{pH} 7 \cdot 2$ ) and $48 \mu \mathrm{l}$ HPLC-grade water (Fisher Scientific, Middleton, Manchester, UK). The hybridization mixture $(45 \mu \mathrm{l})$ was added to $5 \mu \mathrm{l}$ each probe $(50 \mathrm{ng} / \mu \mathrm{l})$ and hybridized for $24 \mathrm{~h}$ at either $45^{\circ}$ (Lab158 and Bac303) or 50 (Bif164 and His150). The cells were then re-suspended at their respective hybridization temperatures for $30 \mathrm{~min}$ in $5 \mathrm{ml}$ wash buffer $(20 \mathrm{mM}$-Tris- $\mathrm{HCl}, 0.9 \mathrm{M}-\mathrm{NaCl}, \mathrm{pH} 7 \cdot 2)$ and $20 \mu$ l DAPI $(500 \mathrm{ng} / \mu \mathrm{l})$. Subsequently, cells were vacuum filtered onto a $0 \cdot 2 \mu \mathrm{m}$ GTBP Isopore black membrane filter (Millipore Corporation, Watford, Herts., UK). The filter was mounted onto a microscope slide with SlowFade (Molecular Probes, Leiden, The Netherlands) and examined using a Nikon Microphot EPI fluorescent microscope (Nikon, Kingston upon Thames, Surrey, UK). The DM400 excitation filter was used to illuminate DAPI-stained cells and the DM510

Table 1. Oligonucleotide probes and selective growth media used for the enumeration of gut bacteria*

\begin{tabular}{|c|c|c|}
\hline Target bacteria & $\begin{array}{c}\text { Probe name and } \\
\text { hybridization temperature }\end{array}$ & Culture media \\
\hline Total anaerobes agar & DAPI & Wilkens Chalgren \\
\hline Bacteroides & Bac $303,45^{\circ}$ & $\begin{array}{l}\text { Brucella agar + (/l) } 75 \mathrm{mg} \text { kanamycin; } \\
5 \mathrm{mg} \text { haemin; } 10 \mathrm{ml} \text { phylloquinone; } 75 \mathrm{mg} \\
\text { vancomycin; } 50 \mathrm{ml} \text { laked horse blood }\end{array}$ \\
\hline Bifidobacteria & Bif164, $50^{\circ}$ & $\begin{array}{l}\text { Beerens agar (Columbia agar }+(/ /) \\
5 \mathrm{~g} \text { glucose; } 0.5 \mathrm{~g} \text { cysteine } \mathrm{HCl} \\
0.5 \mathrm{~g} \text { propionic acid) }\end{array}$ \\
\hline Clostridia & His $150 \dagger, 50^{\circ}$ & $\begin{array}{l}\text { Reinforced clostridial agar + (/l) } 8 \mathrm{mg} \\
\text { colistin; } 8 \mathrm{mg} \text { novobiocin }\end{array}$ \\
\hline Lactobacilli & Lab158, $45^{\circ}$ & Rogosa agar $+1.32 \mathrm{ml}$ glacial acetic acid \\
\hline
\end{tabular}


filter was used to count the hybridized cells. A minimum of fifteen fields of view were counted on each slide, with more fields being counted if an abnormal distribution was observed. Each probe was counted in triplicate using this approach.

\section{Statistical analysis}

For both the cultural enumerations and FISH counts, statistically significant changes in bacterial groups at the various incubation times were determined by means of a paired Student's $t$ test.

\section{Results and discussion}

The role of lower-gut function in nutrition and health is currently being researched by a number of groups. One critical aspect of this is a determination of the potential substrates for microbial growth in the colon and the nature of species involved in the metabolism of food products. Bacteria in the large bowel mainly rely on dietary residues for their growth substrates. These are mainly carbohydrate and proteinaceous in nature (Macfarlane et al. 1996; Macfarlane \& Gibson, 1996). The present study used synthesized melanoidins to determine their degradation under in vitro conditions resembling those in the human gastrointestinal tract. Incubation of sample $M$ with pepsin, and sample MP with pancreatin and bile, resulted in no melanoidin degradation products being observed by HPLC on analysis of $\mathrm{MP}(\mathrm{f})$ and $\mathrm{MPB}(\mathrm{f})$. These results indicate that no melanoidin degradation products with nominal molecular masses below $3000 \mathrm{Da}$ were formed using these incubation conditions. In the batch culture fermenters inoculated with gut bacteria, there was no convincing evidence for the presence of melanoidin degradation products in the ultrafiltrates. This may be because they were metabolized by the bacteria as soon as they were formed or because the chosen HPLC conditions were not suitable for the analysis of components such as short-chain fatty acids and free lysine, which could have resulted from bacterial action on the melanoidins. Such materials may contribute towards energy gain from the fermentation process and butyrate is a preferred fuel for colonocyte function (Roediger, 1980; Cummings, 1981). The use of radiolabelled melanoidins and monitoring of labelled melanoidin degradation products would help to clarify their fate.

The results in Tables 2 and 3 show bacterial population differences in response to the fermentation of melanoidins (M). The data indicate that in a substrate-limited environment, such as that imposed on the faecal inoculum here, bacterial increases occur in response to melanoidin fermentation. That is, sample $\mathrm{M}$, or products of its bacterial metabolism, acted as an electron donor in the anaerobic environment of the fermenter.

Table 2 used plate culture techniques to identify the community dynamics. For the total anaerobes, bacteroides and clostridia, a statistically significant increase was evident after both $6 \mathrm{~h}$ and $24 \mathrm{~h}$ incubations. For the bifidobacteria, this occurred after $24 \mathrm{~h}$, whilst there was no marked increase in lactobacilli. In contrast, the use of a molecular probing procedure indicated that statistically significant changes occurred after $24 \mathrm{~h}$ incubation, and that this was the case for bacteroides, clostridia and lactobacilli, but not total anaerobes or bifidobacteria (Table 3). No significant increases were detected, using probes, after $6 \mathrm{~h}$. Counts of lactobacilli were always higher through the genotypic approach. This was, at least partially, due to the fact that the probe used (Lab158) was also designed to hybridize with enterococci.

The fermentation data clearly indicate that the melanoidins affected the gut bacteria, although HPLC evidence for the presence of melanoidin degradation products was inconclusive. The observed increases in lactobacilli agree with both pure culture (Jemmali, 1969) and rat (Horikoshi et al. 1981) fermentation studies with Maillard reaction products. The influence of Maillard reaction products, prepared from glucose and glycine, on some intestinal bacteria (Lactobacillus arabinosus, L. casei, L. acidophilus and Escherichia coli) in vitro has been reported (Jemmali, 1969). The total Maillard reaction products were shown to reduce the lag phase of the lactobacilli by $10-30 \%$, but to increase that of $E$. coli. The amount and rate of growth increased for lactobacilli only. However, such pure culture studies do not give an adequate reflection of in situ events, where competitive interactions between the resident microbiota are intense. In a study using rats, it was demonstrated that the feeding of total Maillard products (high and low molecular mass) caused increases in the growth of

Table 2. Effects of the fermentation of melanoidins (sample M, Fig. 1) in batch culture fermenters on numbers of faecal bacteria $\left(\log _{10}\right.$ bacterial counts/g wet weight of faeces from triplicate dilution series) as evidenced by enumeration on agar plates $\dagger$

(Mean values and standard deviations)

\begin{tabular}{llccccc}
\hline $\begin{array}{l}\text { Incubation } \\
\text { time }(\mathrm{h})\end{array}$ & $\begin{array}{c}\text { Total } \\
\text { anaerobes }\end{array}$ & Bacteroides & Clostridia & Bifidobacteria & Lactobacilli \\
\hline 0 & Mean & 8.71 & 7.16 & 7.4 & 8.37 & 5.32 \\
& SD & 0.1 & 2.12 & 0.1 & 0.08 & 2.14 \\
6 & Mean & $10.1^{*}$ & $8.39^{*}$ & $8.63^{*}$ & 8.93 & 6.15 \\
& SD & 0.1 & 0.25 & 1.2 & 0.09 & 1.74 \\
24 & Mean & $10.68^{*}$ & $10.25^{*}$ & $9.96^{*}$ & $10.1^{*}$ & 6.06 \\
& SD & 0.1 & 0.4 & 0.06 & 0.1 & 2.37 \\
\hline
\end{tabular}

Mean values were significantly different from those for $0 \mathrm{~h}:{ }^{*} P<0.05$.

†Fermenters were inoculated with human faecal bacteria $(10 \mathrm{~g} / \mathrm{l}$ final concentration), operated under anaerobic conditions and at $37^{\circ}$. The experiments were carried out in triplicate. 
Table 3. Effects of the fermentation of melanoidins (sample M, Fig. 1) in batch culture fermenters on numbers of faecal bacteria $\left(\log _{10}\right.$ bacterial counts/g wet weight faeces from triplicate dilution series) as evidenced by fluorescent in situ hybridization (FISH) probes $\dagger$

(Mean values and standard deviations)

\begin{tabular}{ccccccc}
\hline $\begin{array}{l}\text { Incubation } \\
\text { time }(\mathrm{h})\end{array}$ & $\begin{array}{c}\text { Total } \\
\text { anaerobes }\end{array}$ & Bacteroides & Clostridia & Bifidobacteria & Lactobacilli \\
\hline 0 & Mean & 9.61 & 8.7 & 8.2 & 8.71 & 7.36 \\
& SD & 0.2 & 0.25 & 0.1 & 0.1 & 0.3 \\
6 & Mean & 9.62 & 9.03 & 7.97 & 8.7 & 7.61 \\
& SD & 0.5 & 0.7 & 0.5 & 0.09 & 0.1 \\
24 & Mean & 10.36 & $9.93^{*}$ & $9.12^{*}$ & 9.07 & $8.66^{*}$ \\
& SD & 0.21 & 0.3 & 0.4 & 0.34 & 0.2 \\
\hline
\end{tabular}

Mean values were significantly different from those for $0 \mathrm{~h}:{ }^{*} P<0.05$.

†Fermenters were inoculated with human faecal bacteria ( $10 \mathrm{~g} / \mathrm{l}$ final concentration), operated under anaerobic conditions and at $37^{\circ}$. The experiments were carried out in triplicate.

lactobacilli, but had no effect on numbers of enterococci, coliforms or clostridia (Horikoshi et al. 1981).

There are three possible mechanisms by which melanoidins may influence the growth of the gut bacteria, i.e. toxic effects, provision of substrates, and limiting the availability of metal ions due to binding. The nature of these effects will differ according to the composition of the melanoidin material. Elemental analysis of the sample used for the present study gave values of: $\mathrm{C} 44.34 \%, \mathrm{H} 7 \cdot 31 \%, \mathrm{~N}$ $6.95 \%$, giving $\mathrm{O}$ (by difference) $41.40 \%$, corresponding to an empirical formula of $\mathrm{C}_{7 \cdot 44} \mathrm{H}_{14 \cdot 62} \mathrm{NO}_{5.22}$. This suggests a mixture of components which differ in empirical formulas and also little unsaturation or aromaticity (since the $\mathrm{C}: \mathrm{H}$ ratio is about $1: 2$ ).

Viswanathan \& Sarma (1957) demonstrated that autoclaving lactose with various proteins or amino acids resulted in the formation of a substance which inhibited the growth of a Lactobacillus. Selected bacteria appear to be able to use model melanoidins and related materials as a substrate. Terasawa et al. (1996) demonstrated that Coriolus versicolor IFO 30340, Streptomyces werraensis TT14 and Paecilomyces canadensis NC-1 were all able to decolorize model melanoidin prepared from xylose and glycine, but only the former two organisms could decolorize melanoidin made from glucose and lysine. The ability of gut bacteria to degrade these melanoidins was not investigated by the authors. It is well known that Maillard reaction products, including melanoidins, are able to bind certain metal ions (Finot, 1990; O’Brien \& Morrisey, 1997). O'Brien \& Morrisey (1997) reported binding of $\mathrm{Mg}, \mathrm{Cu}, \mathrm{Ca}$ and $\mathrm{Zn}$ to Maillard reaction products prepared from glucose and monosodium glutamate, while Homma et al. (1986) demonstrated that coffee pigments are able to bind $\mathrm{Cu}, \mathrm{Fe}$ and $\mathrm{Zn}$. In the gut, the prevailing $\mathrm{pH}$ will affect complexation of metal ions by melanoidins and thus influence metal ion availability.

The data in Tables 2 and 3 show that probe-based counts were always higher than the equivalent agar plate at the start of the incubation period. This probably reflected the presence of non-culturable diversity in the samples, which would not be recovered through the plating procedure. However, during later stages of the fermentation $(6 \mathrm{~h}$, $24 \mathrm{~h}$ ), counts using the plate procedure were similar, or higher, than those recovered from probes. This probably indicated some adaptation of the microflora towards typical plate cultural nutrients also included in the fermenter basal media.

Traditionally, gut microbiology procedures have relied on the use of viable counting procedures to assess microbiota changes, either in human volunteer trials (Gibson et al. 1995 ) or by using in vitro fermentation studies (Wang \& Gibson, 1993). However, there is now a shift towards the use of molecular principles for detecting gut bacterial responses to fermentable substrates (Collins \& Gibson, 1999). These include gene-sequencing procedures that can more effectively identify bacterial colonies on plates (Ward et al. 1992; Snel et al. 1995), as well as direct community analyses that obviate the need for culture procedures (Amann et al. 1995; Zoetendal et al. 1998). One attractive approach is the use of $16 \mathrm{~S}$ rRNA-based probes that can identify the microbiota of mixed samples such as gut contents. On a quantifiable basis, FISH has been used for this purpose (Langendijk et al. 1995; HJM Harmsen, GR Gibson, P Elfferich, GC Raangs, ACM Wideboer-Veloo, A Argaiz, MB Roberfroid and GW Welling, unpublished results).

In the present study we applied both plate culture and the FISH technology to determine how predominant gut bacteria react to the fermentation of Maillard reaction products. The rationale is that such products are widespread in the typical Western diet and may have an impact on gut bacterial metabolism. Use of both microbiological procedures showed that melanoidins are metabolized by faecal micro-organisms. However, 16S-rRNA probing (Table 3) indicated a slower fermentation than did the use of viable plate counting (Table 2). Using a phenotypic approach, a significant increase in bifidobacteria occurred (Table 2). However, this was not the case with probes (Table 3 ). As the probes used here have been validated for their use in gut contents, it likely that this approach will give the more accurate reflection of fermentation events.

The conclusions of this study are two-fold. (1) Human gut microflora are affected by melanoidins. O'Brien \& Morrissey (1989) suggested that the effects of Maillard reaction products on gut microflora may be similar to those of lactose and other poorly digestible carbohydrates. The degradation of melanoidins in the large intestine may also play a role in the binding and/or release of other dietary components. 
(2) A genotypic approach to the fermentation shows discrepancies with the more frequently used plate culture technique. Imminent developments should encompass both approaches to the bacteriology. However, the adaptation of molecular principles to gut fermentation opens up the possibility of volunteer trials that exploit a high fidelity approach and allow multiple-centre trials to be carried out (as the samples can be stored before detection of the bacteria).

\section{Acknowledgements}

Dr R. G. Bailey and Dr A. M. Minihane are thanked respectively for help and advice with the preparation and HPLC of the melanoidins and with the pepsin and pancreatin digestions.

\section{References}

Amann RI, Ludwig W \& Schleifer KH (1995) Phylogenetic identification and in situ detection of individual microbial cells without cultivation. Microbiological Reviews 59, 143-169.

Ames JM (1992) The Maillard reaction. In Progress in Food Proteins - Biochemistry, pp. 99-153 [BJF Hudson, editor]. London: Elsevier Applied Science.

Ames JM (1998) Applications of the Maillard reaction in the food industry. Food Chemistry 62, 431-439.

Ames JM \& Nursten HE (1989) Recent advances in the chemistry of coloured compounds formed during the Maillard reaction. In Trends in Food Science, pp. 8-14 [WS Lien and CW Foo, editors]. Singapore: Singapore Institute of Food Science and Technology.

Bailey RG, Ames JM \& Monti SM (1996) An analysis of nonvolatile reaction products of aqueous Maillard model systems at $\mathrm{pH} 5$, using reversed-phase HPLC with diode array detection. Journal of the Science of Food and Agriculture 72, 97-103.

Collins MD \& Gibson GR (1999) Probiotics, prebiotics and synbiotics: dietary approaches for the modulation of microbial ecology. American Journal of Clinical Nutrition 69, Suppl., 1052S-1057S.

Cummings JH (1981) Short chain fatty acids in the human colon. Gut 22, 763-779.

De Lara RC \& Gilliland SE (1985) Growth inhibition of microorganisms in refrigerated milk by added Maillard reaction products. Journal of Food Protection 48, 138-141.

Finot PA (1990) Metabolism and physiological effects of Maillard reaction products (MRP). In The Maillard Reaction in Food Processing, Human Nutrition and Physiology, pp. 259-271 [PA Finot, HU Aeschbacher, RF Hurrell and R Liardon, editors]. Basel: Birkhäuser.

Finot PA \& Magnenat E (1981) Metabolic transit of early and advanced Maillard products. In Maillard Reactions in Food, pp. 193-207 [C Eriksson, editor]. Oxford: Pergamon Press.

Franks AH, Harmsen HJM, Raangs GC, Jansen GJ, Schut F \& Welling GW (1998) Variations of bacterial populations in human feces measured by fluorescent in situ hybridization with groupspecific 16S rRNA-targeted oligonucleotide probes. Applied and Environmental Microbiology 64, 3336-3345.

Freter R (1983) Mechanisms that control the microflora. In Human Intestinal Microflora in Health and Disease, pp. 35-54 [DJ Hentges, editor]. London: Academic Press.

Fuller R (editor) (1992) Probiotics: The Scientific Basis. London: Chapman \& Hall.

Fuller R (editor) (1997) Probiotics 2: Application and Practical Aspects. London: Chapman \& Hall.
Fuller R \& Gibson GR (1997) Modification of the intestinal microflora using probiotics and prebiotics. Scandinavian Journal of Gastroenterology 32, 28-31.

Gibson GR, Beatty ER, Wang X \& Cummings JH (1995) Selective stimulation of bifidobacteria in the human colon by oligofructose and inulin. Gastroenterology 108, 975-982.

Gibson GR \& Roberfroid MB (1995) Dietary modulation of the human colonic microbiota: introducing the concept of prebiotics. Journal of Nutrition 125, 1401-1412.

Gibson GR, Willems A, Reading S \& Collins MD (1996) Fermentation of non-digestible oligosaccharides by human colonic bacteria. Proceedings of the Nutrition Society 55, 899-912.

Gilliland SE (1990) Health and nutritional benefits from lactic acid bacteria. FEMS Microbiology Reviews 87, 175-188.

Homma S, Aida K \& Fujimaki M (1986) Chelation of metal with brown pigments in coffee. In Amino-Carbonyl Reactions in Food and Biological Systems, pp. 165-172 [M Fujimaki, M Namiki and H Kato, editors]. Amsterdam: Elsevier.

Homma S \& Fujimaki M (1981) Growth response of rats fed a diet containing nondialyzable melanoidin. In Maillard Reactions in Food, pp. 209-216 [C Eriksson, editor]. Oxford: Pergamon Press.

Horikoshi M, Ohmura M, Gomyo T, Kuwabara Y \& Ueda S (1981) Effects of browning products on the intestinal microflora of the rat. In Maillard Reactions in Food, pp. 223-228 [C Eriksson, editor]. Oxford: Pergamon Press.

Jemmali M (1969) Influence of the Maillard reaction products on some bacteria of the intestinal flora. Journal of Applied Bacteriology 32, 151-155.

Kok RG, De Waal A, Schut F, Welling GW, Weenk G, Hellingwerf KJ, Wilkinson MHF \& Welling GW (1996) Specific detection and analysis of a probiotic Bifidobacterium strain in infant feces. Applied and Environmental Microbiology 62, 3668-3672.

Langendijk PS, Schut F, Jansen GJ, Raangs GC, Kamphuis GR, Wilkinson MHF \& Welling GW (1995) Quantitative fluorescence in situ hybridization of Bifidobacterium spp. with genus-specific 16S rRNA-targeted probes and its application in faecal samples. Applied and Environmental Microbiology 61, 3069-3075.

Ledl F \& Schleicher E (1990) New aspects of the Maillard reaction in foods and in the human body. Angewandte Chemie International Edition in English 29, 565-594.

Lee IE, van Chuyen N, Hayase F \& Kato F (1992) Absorption and distribution of $\left[{ }^{14} \mathrm{C}\right]$ melanoidins in rats and the desmutagenicity of absorbed melanoidins against trp-P-1. Bioscience, Biotechnology and Biochemistry 56, 21-23.

McCartney AL, Wenzhi W \& Tannock GT (1996) Molecular analysis of the composition of the bifidobacterial and lactobacillus microflora of humans. Applied and Environmental Microbiology 62, 4608-4613.

Macfarlane GT, Cummings JH \& Allison C (1996) Protein degradation by human intestinal bacteria. Journal of General Microbiology 132, 1647-1656.

Macfarlane GT \& Gibson GR (1996) Carbohydrate fermentation, energy transduction and gas metabolism in the human large intestine. In Ecology and Physiology of Gastrointestinal Microbes. Vol. 1. Gastrointestinal Fermentation and Ecosystems, pp. 269-318 [RI Mackie and BA White, editors]. London: Chapman \& Hall.

Manz W, Amann R, Ludwig W, Vancanneyt M \& Schleifer KH (1996) Application of a suite of 16S rRNA-specific oligonucleotide probes designed to investigate bacteria of the phylum cytophaga-flavobacter-bacteroides in the natural environment. Microbiology-UK 142, 1097-1106.

Minihane AM, Fox TE \& Fairweather-Tait SJ (1993) A continuous flow in vitro method to predict bioavailability of iron from foods. Bioavailability 93, 175-179.

Murata M, Terasawa N \& Homma S (1992) Screening of 
microorganisms to decolorize a model melanoidin and the chemical properties of a microbially treated melanoidin. Bioscience, Biotechnology and Biochemistry 56, 1182-1187.

Nair BM, Oste R, Asp NG \& Pernemalm P-A (1981) Absorption and distribution of a $\mathrm{C}^{14}$-glucose lysine reaction mixture in the rat. In Maillard Reactions in Food, pp. 217-222 [C Eriksson, editor]. Oxford: Pergamon Press.

Noltes AW \& Chappel CA (1985) Toxicology of caramel colours: current status. In Food Toxicology - Real or Imaginary Problems?, pp. 214-228 [GG Gibson and R Walker, editors]. London and Philadelphia, PA: Taylor and Francis.

O'Brien J \& Morrissey PA (1989) Nutritional and toxicological aspects of the Maillard browning reaction in foods. Critical Reviews in Food Science and Nutrition 28, 211-248.

O'Brien J \& Morrisey PA (1997) Metal complexation by products of the Maillard reaction. Food Chemistry 58, 17-27.

O'Brien J, Nursten HE, Crabbe MJC \& Ames JM (editors) (1998) The Maillard Reaction in Foods and Medicine. Cambridge: Royal Society of Chemistry.

Porter KG \& Feig YS (1980) The use of DAPI for identifying and counting aquatic microflora. Limnology and Oceanography $\mathbf{2 5}$, 943-948.

Rizzi G (1997) Chemical structure of colored Maillard reaction products. Food Reviews International 13, 1-28.

Roberfroid MB, Bornet F, Bouley C \& Cummings JH (1995) Colonic microflora: nutrition and health. Nutrition Reviews 53, 127-130.

Roediger WEW (1980) Role of anaerobic bacteria in the metabolic welfare of the colonic mucosa of man. Gut 21, 793-798.

Royle L, Bailey RG \& Ames JM (1998) Separation of Maillard reaction products from xylose-glycine and glucose-glycine model systems by capillary electrophoresis and comparison to reverse phase HPLC. Food Chemistry 62, 425-430.
Salminen S, Bouley C, Boutron-Ruault MC, Cummings JH, Franck A, Gibson GR, Isolauri E, Moreau MC, Roberfroid M \& Rowland I (1998) Functional food science and gastrointestinal physiology and function. British Journal of Nutrition 80, S147-S171.

Simon G \& Gorbach SL (1984) Intestinal flora in health and disease. Gastroenterology 86, 174-193.

Snel J, Heinen PP \& Blok HJ (1995) Comparison of 16S rRNA sequences of segmented filamentous bacteria isolated from mice, rats and chickens and proposal of 'Candidatus arthromitus'. International Journal of Systematic Bacteriology 45, $1780-1782$.

Terasawa N, Murata M \& Homma S (1996) Comparison of brown pigments in foods by microbial decolorization. Journal of Food Science 61, 669-672.

Viswanathan L \& Sarma PS (1957) A growth inhibitor of $L$. bulgaricus 09. Nature 180, 1370-1371.

Wang X \& Gibson GR (1993) Effects of the in vitro fermentation of oligofructose and inulin by bacteria growing in the human large intestine. Journal of Applied Bacteriology 75, 373-380.

Ward DM, Bateson MM, Weller R \& Ruffroberts AL (1992) Ribosomal RNA analysis of microorganisms as they occur in nature. Advances in Microbial Ecology 21, 219-286.

Wilson KH \& Blitchington RB (1996) Human colonic biota studied by ribosomal DNA sequence analysis. Applied and Environmental Microbiology 62, 2273-2278.

Zoetendal EG, Akkermans ADL \& De Vos WM (1998) Temperature gradient gel electrophoresis analysis of 16S rRNA from human fecal samples reveals stable and host-specific communities of active bacteria. Applied and Environmental Microbiology 64, 3854-3859. 